\title{
Efek Pemberian Gentamisin Secara Oral Terhadap Kadar Asam Urat, Ureum, dan Kreatinin Tikus Wistar
}

\author{
Syahrul Ardiansyah'), Galuh Ratmana Hanum \\ ${ }^{1)}$ Program Studi Teknologi Laboratorium Medis, Fakultas Ilmu Kesehatan, Universitas \\ Muhammadiyah Sidoarjo. \\ Email : ${ }^{1}$ syahrulardiansyah@umsida.ac.id \\ galuhratmanahanum@ymail.com
}

Tanggal Submit:

23 Oktober 2018

Tanggal Review:

15 November 2018

Tanggal Publish

Online:

29 Desmber 2018

\begin{abstract}
Gentamicin is an aminoglycoside class of antibiotics which at high doses can cause damage to the kidneys. This research was to determine the levels of BUN, creatinine and amino acids after gentamicin induction. This research is experimental with gentamicin test material given to male rats as much as $0.3 \mathrm{ml} /$ day for 7 and 10 days. Blood serum levels were then measured for BUN, creatinine and amino acids using a photometer microlab 300. The results showed that after doing treatment for 7 days the average value of BUN levels increase from 21.7 to $36.3 \mathrm{mg} / \mathrm{dl}$, creatinine increase from 0,88 to 1.9 $\mathrm{mg} / \mathrm{dl}$, uric acid increase from 1.54 to $4.29 \mathrm{mg} / \mathrm{dl}$. It was concluded that giving of gentamicin as much as $0.3 \mathrm{ml} /$ day for 7 and 10 days increased BUN levels, creatinine and uric acid exceeded the normal limit.
\end{abstract}

Keywords : Gentamicin, urea, creatinine, uric acid, rat.

\section{PENDAHULUAN}

Gentamisin adalah salah satu jenis antibiotik golongan aminoglikosida yang digunakan untuk infeksi yang disebabkan oleh bakteri. Selain memiliki manfaat sebagai antibiotik, gentamisin juga memiliki efek samping jika diberikan pada dosis yang berlebih. Salah satu dampak yang diakibatkan oleh pemberian gentamisin dengan dosis berlebih adalah kerusakan pada organ yang terpapar termasuk salah satunya adalah ginjal. Penelitian yang dilakukan oleh Razak, et al (2016) menunjukkan hasil adanya kerusakan pada organ ginjal tikus wistar yang diinjeksi gentamisin dengan dosis $0,3 \mathrm{ml} /$ hari dalam kurun waktu 6 hari berupa pembengkakan (degenerasi hidropik) sel epitel tubuli dimana sel membesar dan terdapat nekrosis pada beberapa sel-sel epitel tubuli.

Kerusakan yang terjadi pada ginjal akan berdampak pada penurunan fungsi ginjal. Gangguan pada fungsi ginjal akan berdampak terganggunya penyaringan pada glomerulus sehingga laju filtrasi mengalami penurunan dan 
mengakibatkan terganggunya filtrasi

kreatinin di glomerulus serta ekskresi urea. Kadar urea dan kreatinin dapat digunakan sebagai indikator untuk mengetahui adanya gangguan pada fungsi ginjal (Guyton dan Hall, 2007). Ganguan proses filtrasi pada ginjal juga berpotensi menyebabkan kenaikan kadar asam urat. Hiperurisemia bisa terjadi karena produksi asam urat yang berlebih atau ekskresi yang menurun (Mantiri et al, 2017).

\section{METODE PENELITIAN}

Penelitian ini bersifat eksperimental yang dilakukan di laboratorium kimia klinik Fakultas Ilmu Kesehatan Universitas Muhammadiyah Sidoarjo. Hewan uji menggunakan tikus wistar jantan dengan berat badan \pm 200 gram yang ditempatkan pada bak plastik ukuran $36 \mathrm{~cm}$ x $30 \mathrm{~cm}$. Masing-masing bak perlakuan diberi sekam sebagai alas, diisi 2 ekor tikus yang diberi pakan pelet dan minum setiap hari. Sebelum perlakuan tikus diaklimatisasi terlebih dahulu pada suhu ruangan $\left(27^{\circ} \mathrm{C}\right)$ selama 7 hari.

Bahan uji yang digunakan adalah gentamisin $40 \mathrm{mg} / \mathrm{ml}$ yang diperoleh dari unit farmasi rumah sakit DKT Sidoarjo. Bahan uji diberikan pada tikus sebanyak $60 \mathrm{mg} / \mathrm{kgBB} / \mathrm{hari}$, yang setara dengan 0,3 ml/hari (Lintong et al, 2012). Penelitian dibagi dalam tiga kelompok perlakuan yakni kelompok 1 berisi 8 ekor tikus tanpa pemberian gentamisin; kelompok 2 berisi 8 ekor tikus yang diinduksi gentamisin secara oral selama 7 hari dengan dosis $0,3 \mathrm{ml} / \mathrm{hari}$; kelompok 3 berisi 8 ekor tikus yang diinduksi gentamisin secara oral selama 10 hari dengan dosis $0,3 \mathrm{ml} / \mathrm{hari}$.

Setelah perlakuan darah tikus diambil melalui aorta untuk memperoleh serum. Serum yang diperoleh kemudian diukur kadar ureum (BUN), kreatinin, dan asam urat menggunakan metode kalorimetri menggunakan alat fotometer microlab 300 dengan reagen Elitech. Hasil penelitian kemudian dianalisis secara deskriptif kuantitatif untuk mengetahui apakah nilai BUN, kreatinin, dan asam urat setelah perlakuan mengalami kenaikan hingga melebihi nilai normal.

\section{HASIL DAN PEMBAHASAN}

Ginjal merupakan salah satu organ vital pada manusia yang memiliki fungsi ekskresi. Hasil buangan tertentu seperti hasil proses metabolisme berupa urea, kreatinin, asam urat yang tidak dibutuhkan oleh tubuh akan difiltrasi oleh ginjal untuk kemudian dibuang bersama urin. Ekskresi pada ginjal sangat dipengaruhi oleh filtrasi glomerulus dan reabsorbsi tubulus. Semakin besar laju filtrasi yang dilakukan oleh glomerulus membuat 
ginjal mampu mengekskresi produk buangan dari tubuh seperti ureum, kreatinin, asam urat dengan cepat (Guyton dan Hall, 2007).

Ureum dan kreatinin merupakan hasil dari metabolisme protein. Kadar ureum dan kreatinin merupakan uji yang sering dilakukan untuk pemeriksaan ginjal, selain itu juga bisa digunakan kadar albumin (Suryawan et al, 2016). Hasil penelitian menunjukkan setelah pemberian gentamisin selama 7 dan 10 hari terjadi kenaikan nilai kadar Blood Urea Nitrogen (BUN) (Gambar 1) dan kadar kreatinin (Gambar 2) jika dibandingkan dengan nilai normal. Menurut Malole dan Pramono (1989) nilai normal BUN pada tikus sebesar 15$21 \mathrm{mg} / \mathrm{dl}$, sedangkan untuk kreatinin sebesar $0,2-0,8 \mathrm{mg} / \mathrm{dl}$.

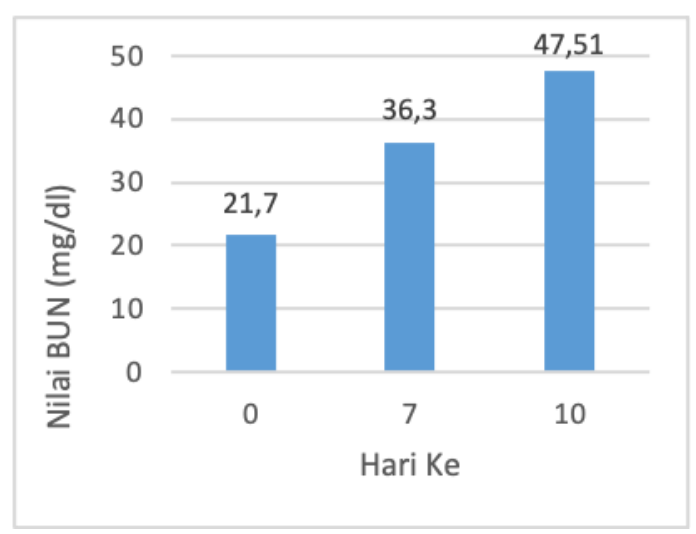

Gambar 1. Diagram rerata kadar BUN setelah perlakuan

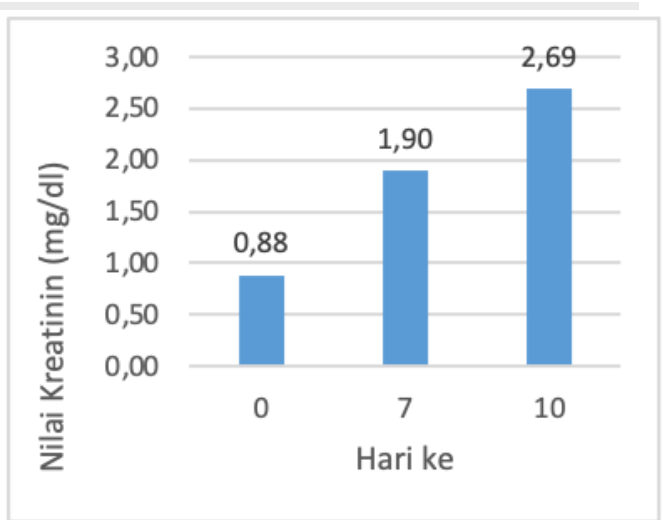

Gambar 2. Diagram rerata kadar kreatinin setelah perlakuan

Kreatinin merupakan hasil metabolisme kreatin fosfat, sedangkan ureum adalah hasil dari metabolisme protein yang terjadi dalam tubuh. Kadar ureum dipengaruhi proses pemecahan protein didalam hati yang selanjutnya akan dibawa menuju ginjal untuk dilakukan filtrasi kemudian dibuang melalui urin. Nilai BUN dan kreatinin yang tinggi mengindikasikan tingginya kadar urea dan kreatinin di dalam darah. Menurut Tondi et al (2017) jika laju filtrasi glomerulus meningkatkan, maka proses urinasi akan meningkat sehingga zat nefrotoksik akan dikeluarkan.

Gentamisin yang masuk kedalam tubuh akan disekresikan melalui ginjal, pada kadar berlebih akan terjadi penumpukan gentamisin pada ginjal terutama sel epitel tubulus ginjal yang menyebabkan gangguan produksi ATP sehingga proses respirasi pada mitokondria akan terganggu dan menyebabkan nekrosis (Razak et al, 2016). Kerusakan pada ginjal 
menyebabkan menurunnya kemampuan

filtrasi oleh glomerulus yang akan menurunkan proses urinasi sehingga zat nefrotoksik tidak dapat diekskresikan dengan baik, selain itu juga berdampak terganggunya filtrasi kreatinin di glomerulus serta ekskresi urea sehingga kadar urea dan kreatinin di dalam darah akan meningkat (Guyton dan Hall, 2007).

Hasil pengukuran asam urat menunjukkan kenaikan setelah dilakukan induksi dengan gentamisin selama 7 dan 10 hari (Gambar 3). Setelah perlakuan 7 hari nilai asam urat sudah melebihi nilai normal. Penelitian yang dilakukan oleh Nakagawa et al (2006) pada tikus Sprague-Dawley menunjukkan nilai normal asam urat berada pada kisaran 0,5-1,4 mg/dl.

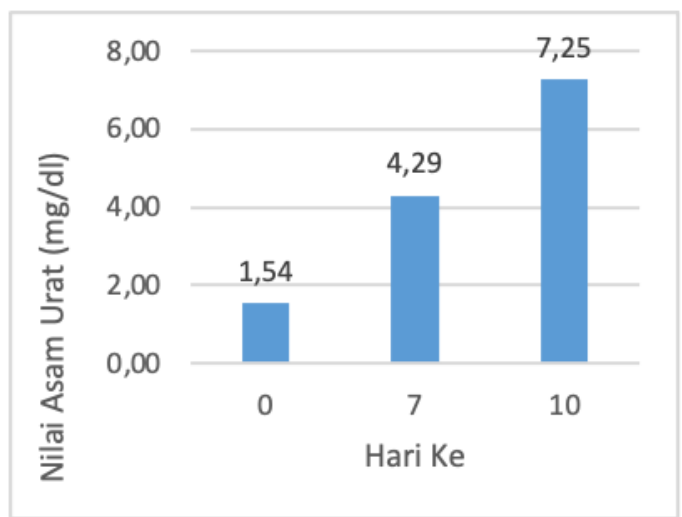

Gambar 3. Diagram rerata kadar asam urat setelah perlakuan

Kadar asam urat pada perlakuan kontrol sebesar 1,54 mg/dl yang melebihi kisaran normal namun belum termasuk hiperurisemia. Tikus dikategorikan hiperurisemia jika nilai asam urat melebihi $1,7 \mathrm{mg} / \mathrm{dl}$ (Nakagawa et al, 2006). Asam urat adalah hasil metabolisme dari purin yang merupakan salah satu komponen asam nukleat di dalam inti sel. Kadar asam urat dipengaruhi oleh tiga faktor yaitu faktor genetik, produksi dan ekskresi, serta faktor usia (Utami et al, 2009). Faktor produksi dan eksresi oleh tubuh merupakan faktor yang dominan mempengaruhi kadar asam urat dalam tubuh. Ketika terjadi kerusakan pada ginjal akibat induksi gentamisin dalam kadar berlebih akan menyebabkan penurunan fungsi ginjal sehingga proses fisiologis pada ginjal yakni ekskresi zat sisa termasuk asam urat akan mengalami penurunan (Pranata, 2013).

Menurut Silbernagl \& Lang (2012) Kadar asam urat yang berlebih akan mengendap pada persendian yang menyebabkan pembentukan garam monosodium urat (MSU) dan berpotensi menyebabkan atritis gout. Pada beberapa kasus penyakit gagal ginjal kronik jarang ditemukan adanya asam urat dengan konsentrasi yang tinggi, diduga ketika pengeluaran melalui ginjal mengalami hambatan maka ekskresi asam urat melalui ekstra renal akan mengalami peningkatan. 


\section{SIMPULAN DAN SARAN}

\section{Simpulan}

Pemberian gentamisin secara oral pada tikus selama 7 dan 10 hari dengan dosis $0,3 \mathrm{ml} / \mathrm{hari}$ sudah meningkatkan kadar BUN, Kreatinin, dan asam urat melebihi batas normal.

Saran

Bisa dilakukan penelitian untuk mengetahui dampak gentamisin dengan dosis berlebih pada organ tubuh yang lain seperti hati yang berfungsi menetralisir racun dalam tubuh.

\section{DAFTAR PUSTAKA}

Guyton, \& Hall, JE., 2007, Buku Ajar Fisiologi Kedokteran (Terjemahan), 11 ed, Rachman RY., Hartanto H., Novrianti A., Wulandari N., editors, Jakarta: EGC.

Lintong, MP., Kairupan, CF., Sondakh PLN., 2012, Gambaran Mikroskopik Ginjal Tikus Wistar (Rattus norvegicus) Setelah Diinduksi Dengan Gentamisin, Jurnal Biomedik, Volume 4, Nomor 3, 185-192.

Malole, MBM., \& Pramono, CSU., 1989, Pengantar Hewan-hewan Percobaan di Laboratorium, Bogor : Pusat Antara Universitas Bioteknologi IPB.

Mantiri INRI., Glady IR., Mayer FW., 2017, Gambaran Kadar Asam Urat pada Pasien Penyakit Ginjal Kronik Stadium 5 yang Belum Menjalani Hemodialisis, Jurnal e-Biomedik (eBm), Volume 5, Nomor 2.
Nakagawa, T., Mazzali, M., Kang, DH., Sánchez-Lozada LG., HerreraAcosta J., Johnson, RJ., 2006, Uric Acid - A Uremic Toxin?, Blood Purif, 24:67-70.

Pranata, PB., 2013, Hubungan Kadar Asam Urat Dalam Darah Pada Penderita Penyakit Ginjal Kronik Dengan Kejadian Artritis Gout di RSUD dr.Moewardi, Skripsi, Fakultas Kedokteran, Universitas Muhammadiyah Surakarta.

Rajak, ZFW., Lily, L., Poppy, L., 2016, Gambaran Histopatologik Ginjal Wistar Yang Diberi Ekstrak Binahong Pasca Pemberian Gentamisin, Jurnal e-Biomedik $(\mathrm{eBm})$, Volome 4, Nomer 2.

Silbernagl, S., \& Lang, F., 2012, Gagal Ginjal Kronis: Gangguan Fungsi, Dalam : Teks \& Atlas Berwarna Patofisiologi, Jakarta: EGC.

Suryawan, DGA., Arjani, IAMS., Sudarmanto I.G., 2016, Gambaran Kadar Ureum Dan Kreatinin Serum Pada Pasien Gagal Ginjal Kronis Yang Menjalani Terapi Hemodialisis Di Rsud Sanjiwani Gianyar, Jurnal Meditory, Vol. 4, No.2.

Tandi, J., Ayu, W., Asrifa, 2017, Efek Ekstrak Etanol Daun Gendola Merah (Basella alba L.) terhadap Kadar Kreatinin, Ureum dan Deskripsi Histologis Tubulus Ginjal Tikus Putih Jantan (Rattus norvegicus) Diabetes yang Diinduksi Streptozotocin, Jurnal Farmasi Galenika, Volume 3 (1): 93102. 
Utami, P., 2009, Solusi Sehat Asam Urat dan Rematik, Jakarta: Agromedia Pustaka.

Yones DA, Bakir HY, Bayoumi SAL. 2016. Chemical composition \& efficacy of some selected plant oils against Pediculus humanus capitis in vitro. Parasitol Res. DOI 10.1007/s00436-016-5083.5.

Yoon KS, Ketzis JK, Andrewes SW, Wu CS, Honraet K,Staljanssens D, Rossel B, Clark JM. 2015. In vitro and in vivo evaluation of infestation deterrents against lice. vector control, pest management, resistance, repellents. J. Med. Entomol. 52 (5): 970-978. DOI: 10.1093/jme/tjv069. 